\title{
Endringer i ultralydtilbudet for gravide i Norge
}

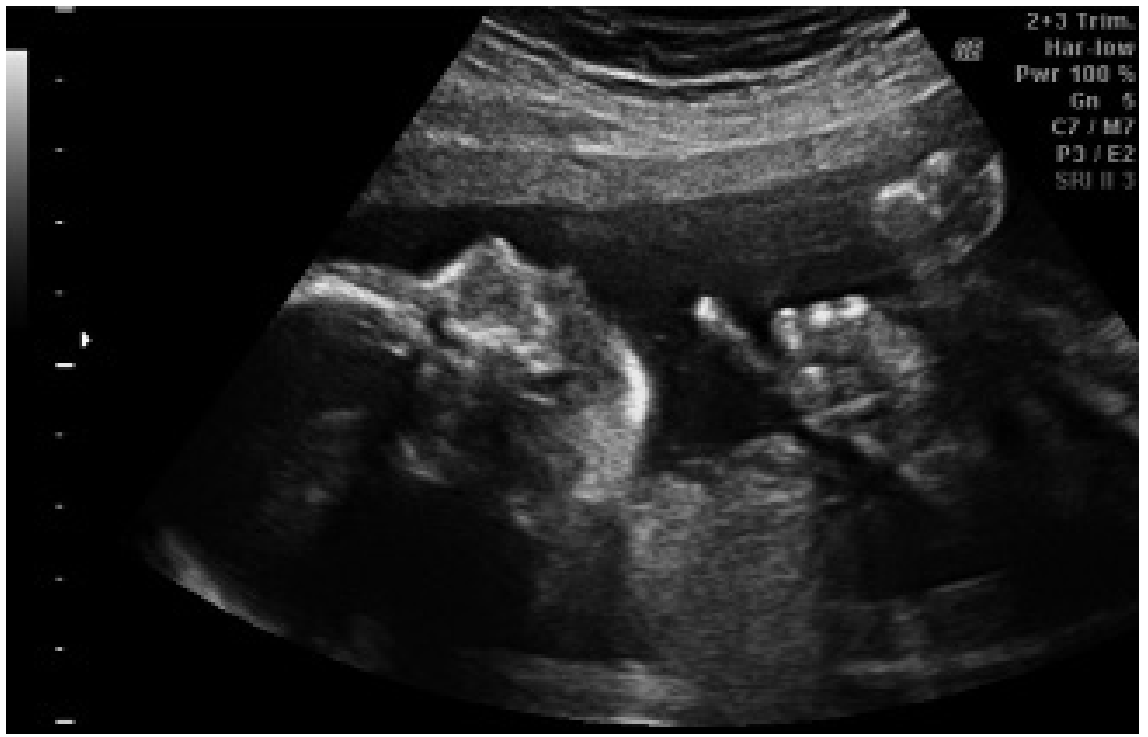

I dag får alle gravide tilbud om en ultralydundersøkelse, den såkalte rutineultralyd mellom svangerskapsuke 17 og 19. Bruk av rutineultralyd ble først anbefalt i 1986, og per i dag benytter nærmest alle gravide seg av tilbudet.

Mens det i starten først og fremst var mer nøyaktig terminbestemmelse med hjelp av måling av biparietal diameter som stod sentralt, ble det fort fokus på systematisk gjennomgang av fosteranatomien.

Utover denne undersøkelsen får kvinner over 38 år, kvinner som tidligere har født et barn med sykdom som kan påvises med hjelp av fosterdiagnostikk, eller kvinner med familiær belastning for slik tilstand tilbud om fosterdiagnostikk. Den utføres i dag oftest i form av kombinert ultralyd og blodprøve (KUB). Ved blodprøven, den såkalte duotesten, bestemmes HCG (human choriongonadotropin) og PAPP-A (placentaassosiert plasmaprotein A).

I Norge har diskusjonen om innføring av en ekstra ultralydundersøkelse rundt uke 12 for alle gravide pågått i alle fall i ti år.

Nasjonalt råd for kvalitet og prioritering offentliggjorde den 5. desember 2011 sitt endelige vedtak. Det siteres:

Nasjonalt råd for kvalitet og prioritering $\mathrm{i}$ helse- og omsorgtjenesten er opptatt av at den offentlige svangerskapsomsorgen skal være sikker, trygg og ha en høy faglig kvalitet.

Rutinemessig ultralyd bør tilbys i uke 1113 og 17-19 for å

- sikre tidligst mulig ivaretakelse av formålet for ultralyd i svangerskapet

- sikre faglig kvalitet av undersøkelsen
Før innføring bør økonomiske og prioriteringsmessige konsekvenser utredes nærmere gjennom egnet pilotering.

Vedtaket baserer seg på Kunnskapssenteret sin vurdering som ble publisert den 16 . februar 2012. Det siteres:

Rutinemessig tidlig ultralydundersøkelse i svangerskapsuke 11-13 kan ha samme formål som dagens tilbud om ultralyd i svangerskapsuke 17-19. Fordi nakkeoppklaring vil bli observert i svangerskapsuke 11-13, vil tidlig ultralyd avdekke flere fostre med risiko for kromosomavvik.

\section{Helseeffekter}

$\nabla$

- Vi fant ingen dokumentasjon for helsemessig gevinst av rutinemessig tidlig ultralyd

- Et tilbud om tidlig ultralyd til alle kan føre til at det fødes færre barn med trisomi 21 (Downs syndrom)

- Vi fant ikke holdepunkter for at ultralydundersøkelser har en direkte skadelig effekt for mor, foster eller barn

- Tidlig ultralyd kan føre til flere kvinner som er fornøyde med svangerskapsomsorgen 
- Betydningen av bedre diagnostisering av tvillinger med felles morkake er uavklart

\section{Diagnostisering av ulike tilstander} $\nabla$

- Tidlig ultralyd kan påvise tilnærmet alle tvillinger som deler morkake, noe som er vanskeligere senere $\mathrm{i}$ svangerskapet

- Det er stor usikkerhet om diagnostisk nøyaktighet for påvisning av alvorlige strukturelle avvik, blant annet hjertefeil

- Måling av nakkeoppklaring kombinert med blodprøver (KUB) er en mer treffsikker metode for å påvise trisomi 21 enn måling av nakkeoppklaring alene

\section{Andre konsekvenser av tidlig ultralyd}

Våre økonomiske modellanalyser viser at innføring av et offentlig finansiert tilbud om tidlig ultralyd som tillegg til ultralyd i uke 17-19, kan føre til en fordobling av driftskostnadene sammenliknet med dagens anbefaling.

Ultralydmiljøet argumenterer stort sett for innføring av et velorganisert tilbud i form av KUB med definerte krav til undersøkerens kvalifikasjon og metodesikkerhet tilsvarende ordningen som brukes i f. eks. Storbritannia og Danmark.

Det finnes derimot stemmer i samfunn og politikk som er sterkt imot en slik løsning, fordi det fryktes et sorteringssamfunn.

Uheldig ville det være å innføre tidlig ultralyd for alle gravide, uten å definere innholdet av en slik undersøkelse og krav til undersøkere. Gevinsten av en slik „halvferdig“ løsning blir da svært tvilsom.

Uansett kommer det for mange avdelinger til å bli både en faglig og økonomisk utfordring, å organisere på landsbasis årlig ca. 60000 ekstra ultralydundersøkelser.

Prof. Sturla H. Eik-Nes har oppdatert oss om den aktuelle utviklingen på årets symposium i Stavanger med sitt innlegg med tittelen „Veke 12 ultralyd - vår nye utfordring?" 